\title{
Innovative Water Management at the Environmental Campus Birkenfeld
}

\author{
Klaus Helling ${ }^{1}$, Dorit Schumann-Bölsche ${ }^{2}$ \\ ${ }^{1,2}$ Umwelt-Campus Birkenfeld - Trier University of Applied Sciences, Germany, \\ *corresponding author: k.helling@umwelt-campus.de
}

\section{Article Info}

\section{Received:}

15 March 2021

Accepted:

25 May 2021

Published:

1 June 2021

DOI:

https://doi.org/10.14710/j

sp.2021.11203

\begin{abstract}
Sustainable water management has a high relevance for universities and this paper describes the innovative water management system at the Environmental Campus Birkenfeld (ECB), which belongs to Trier University of Applied Sciences. The ECB is called the "greenest university" in Germany. Not without reason, because in the GreenMetric Ranking 2018 and 2019 the ECB took sixth place worldwide and was No. 1 in Germany. Ever since the foundation of the $E C B$, sustainable development and circular economy have been the main focus of all activities of the university. In the sustainability strategy, a holistic approach following the German Sustainability Code is pursued, which includes teaching, research, knowledge transfer and university operation. In 2019 the Environmental Campus achieved in the GreenMetric category water, the full score of 1000 points. As part of an integrated zero emissions concept ECB's water management system is based on a meticulously planned water conservation program which includes technological- and management-based solutions to achieve sustainable water resource use at ECB. Within the ECB's wastewater reduction and resource recovery initiative a research project on "Zero Emission Water Management and Nutrient Mining" is converting an existing dormitory in such a way that the separate collection and discharge of the partial streams grey and black water is possible.
\end{abstract}

\section{Keyword:}

Water Management, Zero Emission, UN SDG Clean Water and Sanitation, Environmental Campus Birkenfeld.

\section{The relevance of Sustainable Water Management for Universities}

In the year 2015, the Agenda 2030 for Sustainable Development was signed with 17 Sustainable Development Goals. The 17 SDGs and 169 targets demonstrate the scale and ambition of the Agenda. "They seek to build on the Millennium Development Goals 
and complete what they did not achieve. They are integrated and indivisible and balance the three dimensions of sustainable development: the economic, social and environmental." They aim to end poverty and hunger, in all their forms and dimensions, and to ensure that all human beings can fulfil their potential in dignity and equality and in a healthy environment [1].

SDG Goal 6 "Clean Water and Sanitation" means to ensure availability and sustainable management of water and sanitation for all. The goal addresses universal and equitable access to safe and affordable drinking water, adequate and equitable sanitation and hygiene, improve water quality, substantially increase water-use efficiency, substantially reduce the number of people suffering from water scarcity, protect, and restore water-related ecosystems and implement integrated water resources management at all levels. The interlinkages and integrated nature of the Sustainable Development Goals are of crucial importance in ensuring that the purpose of the Agenda 2030 is realized [1].

UN-Water proposes the following definition of water security: "The capacity of a population to safeguard sustainable access to adequate quantities of and acceptable quality water for sustaining livelihoods, human well-being, and socio-economic development, for ensuring protection against water-borne pollution and water-related disasters, and for preserving ecosystems in a climate of peace and political stability" [2].

Universities are responsible to contribute to the implementation of UN SDGs Agenda 2030 in general and to SDG 6 "Clean Water and Sanitation" in particular. They are the key drivers to educate young people. Their research activities contribute to technological, ecological, economic and social progress and innovation. Knowledge transfer between universities and surrounding organizations enables industry, politics and society to create joint innovation and applied solutions. In this publication, the contribution of the ECB to water security and SDG 6 by innovative water management is adressed. It considers sustainable facility management on the campus, the activities in sustainable research and education, as well as transfer with the regional stakeholders and international cooperation. In this context, it is important to mention, that there are interactivities with other UN SDGs. Examples are the water-food-energy nexus or waterfood-displacement nexus, which describe the interactions in a comprehensive framework and the challenges, especially in regions with water scarcity such as the West Asia North Africa Region (WANA) or sub-Saharan Africa [3]. Water has implications on and interaction with many SDGs, to enumerate some of them: poverty, hunger, good health and wellbeing, innovation and infrastructure, education, partnership and peace. In this publication, not all of them can be considered. The focus is innovative water management, having in mind the holistic sustainable mission on the ECB.

The following sections use the example of the ECB to show how this can be achieved in an exemplary manner. Section two introduces the campus and university with its comprehensive sustainable character; section three includes applied examples such as water conservation, water recycling, zero emission water management and nutrient mining.

\section{Fast Facts about the Environmental Campus Birkenfeld}

The ECB is a campus of Trier University of Applied Sciences. Since the foundation of the ECB in 1996, the concept has included an interdisciplinary education under the framework of circular economy and sustainable development in its two faculties 
Environmental Planning/ Environmental Technology and Environmental Economics/ Environmental Law. Currently, in the year 2020, far above than 2,200 students from over 65 countries are being taught by a total of 60 full professors in two the faculties. They study in 16 Bachelor's and 12 Master's degree programs. The environmental and sustainability concept forms the thematic link and is the "green thread" that connects all courses [4]. In addition, the university and campus have established three main research areas, one of them under the umbrella of Applied Material Flow Management and Circular Economy. This main research area, inspired by our Institute for Applied Material Flow Management (IfaS), is not only one of the research-strongest areas in the unversity, but also with regard to the Universities of Applied Sciences in the federal state of RhinelandPalatinate and throughout Germany $[5,6]$

At the ECB sustainability is implemented and lived holistically. This holistic approach includes in its sustainability strategy beside education, research, and knowledge transfer all management structures and operations. Since 2004 the ECB has been publishing environmental reports, further developed to sustainability reports on an international standard level [4]. In 2020 the ECB presented the declaration of compliance with the German Sustainability Code and documented how the fields of action of sustainable development are implemented [7]. The active participation of all university members is a key driver for sustainable development at the ECB. In 2017 the Green Office was founded providing information on sustainability activities, connecting internal and external stakeholders and making the university and its environment more ecologically, socially and economically sustainable.

The ECB has been awarded in its history by a number of prizes and top position in rankings [8]. In November 2018, the Federal Ministry of Education and Research and the German Commission for UNESCO honored the ECB as an outstanding educational initiative for sustainable development on the highest level to be achieved [9]. Particularly we refer in this publication to the latest UI GreenMetric Ranking 2019: The ECB took sixth place out of more than 780 participating universities from 75 countries worldwide and rank No. 1 in Germany [10]. With this the ECB repeated its success from the former ranking 2018.

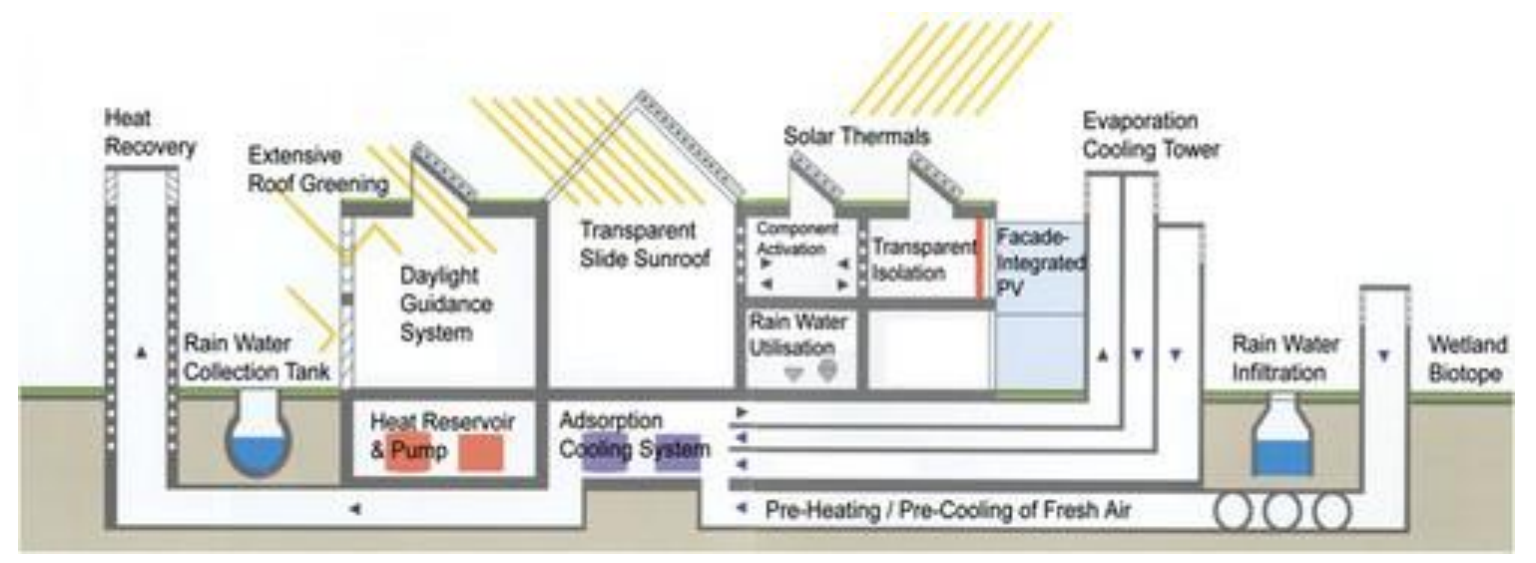

Figure 1. Environmental technologies in Birkenfeld [11]

Accordingly, ECB is called the greenest campus or greenest university in Germany and the first zero emission campus in Europe, making it a role model for many universities around the world [11]. In its sustainable circular economy concept, the campus is composed of connected zero emission elements: E.g., energy and heat are supplied by a nearby biomass heat and power station, which uses waste wood as primary energy source 
[12]. Environmental technical features at the ECB integrate rainwater in its circular economy technical concept with heating and cooling systems and other technologies as shown in Fig. 1.

In addition to education, research, reporting, innovative building standards and environmental technologies, the nearby railway connection and the neighboring National Park Hunsrück-Hochwald, the availability of electrical bicycles and cars for students and staff, vegan breakfast and vegetarian food offer in the canteen, green procurement objectives and activities should be mentioned. For more background about the campus and the campus holistic sustainable approach, a former publication from the International Workshop on UI GreenMetric 2019 [12] and ECB's homepage provide details [4].

Education and research at ECB address special topics of sustainable water management. Specific examples from many programs related to water management are the economic engineering courses Sustainable Business \& Technology (B. Eng.), Industrial Engineering / Environmental Planning (B. Sc.) and International Material Flow Management (M. Sc. and M. Eng.). In addition, other degree programs offer interesting approaches to water management: in Environmental Economics and Business Management (B.A. and M.A.) sustainable business models are considered. In the program "Renewable Energies" (B. Sc.) water is regarded as an energy resource and legal aspects of dealing with water are considered in "Business and Environmental Law" (LL.B.) and in the corresponding master's program "Corporate and Energy Law" (LL.M.). Water-saving technologies are taught in mechanical engineering and questions of water purification are part of process engineering. The computer science courses also offer interesting relations to water management, e.g., via geoinformation systems and corresponding modelling. It is clear that sustainable water management is an interdisciplinary topic which is dealt with in many different ways through the interdisciplinary education at the ECB [13]. As part of the wastewater reduction and resource recovery initiative of the ECB a research project on "Zero Emission Water Management and Nutrient Mining" is converting an existing dormitory in a way that the separate collection and discharge of the partial streams grey and black water is possible (see chapter 3.3). Another outstanding research project "Investigation of renaturalised water bodies" addresses how biodiversity is linked to ecosystem functions / services and the way projects are perceived by stakeholders in the water environment [14].

\section{Sustainable Water Management at the Environmental Campus Birkenfeld}

This publication on innovative water management at the ECB focuses on the results for the category "water" in the GreenMetric Ranking 2019, which are of high relevance and particular interest. In this category the ECB achieved the full score of 1000 points [10]. The ECB's sustainable water management system is based on a holistic water conservation program (see chapter 3.1), furthermore ECB has implemented several solutions for water recycling which are explained in chapter 3.2. Finally, in chapter 3.3 an ongoing research project, that consists of the implementation of an innovative wastewater disposal concept (separate collection and use of wastewater and biomass potentials) in existing buildings at the ECB, is described.

\subsection{Water conservation}

At the ECB a holistic water conservation program is implemented. It includes both technological- and management-based solutions to achieve sustainable water resource 
use at ECB. The water conservation program aims at (a) increasing the water use efficiency (to reduce the overall water consumption/withdrawal) and (b) reduction of environmental impacts associated with the use of water resources.

As part of ECB's policy of using state-of-the-art high-efficient technologies, the water infrastructure also employs water-efficient equipment. A number of technological solutions have been implemented at ECB to increase water use efficiency. They include waterless urinals, low-flow toilets and automated, high-efficient faucets (see Fig. 2). Of particular ecological and economic interest are waterless urinals that do not consume water during use. In total, each replaced water-flushed urinal in the commercial sector saves up to 50,000 liters of water per year. The huge water savings also results energy savings of several hundred kWh per year and piece, including preparation, transport and wastewater treatment, and thus also a reduction of $\mathrm{CO} 2$ emissions. The water pollution is reduced due to less wastewater and fewer pollutants in the water, because no detergents and toilet stones with a high tenside and acid content are used. Waterless urinals pay for themselves after a few months to a few years, depending on the area of application. Compared to conventional systems, savings in operating costs (water, cleaning, maintenance) as well as in the cost-effective construction of new urinals are realized [15].

At the ECB, the installed water flushed urinals are replaced step by step by waterless urinals. This saves money and reduces the environmental impacts. At the moment about $60 \%$ have been replaced and more are added every year. The waterless systems are particularly attractive for regions with water shortages and high-water costs. The positive social effects should not remain unmentioned, because waterless urinal systems work more hygienically than conventional systems: The surface contamination by bacteria and mold is only a fraction of that of water-flushed urinals. The comparison of optics and smell nuisance of frequently frequented urinal systems precipitates clearly in favor of the waterless system. In addition, the cleaning personnel is relieved. For the remaining urinals and the toilets collected rainwater is used (see chapter 4.2) which is generally sufficient to cover a significant share of the water demand of toilets at ECB

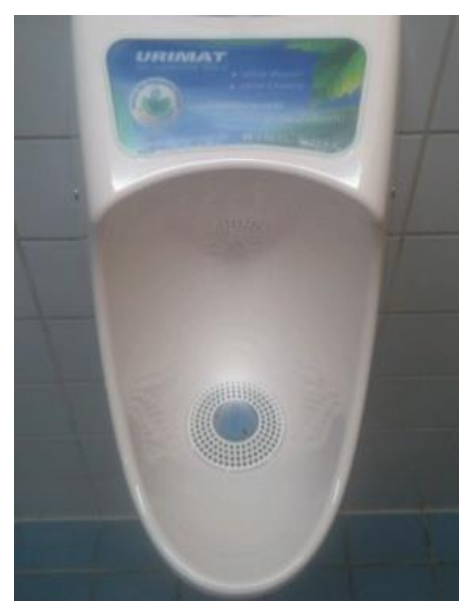

A. Waterless urinals

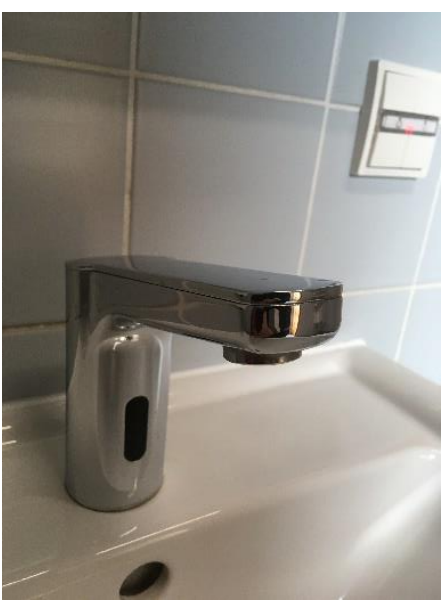

B. High-efficient faucets

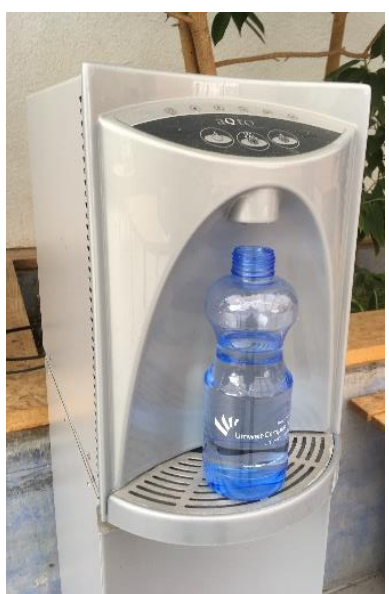

C. Water Dispenser

Figure 2. Water-efficient appliances at ECB

With regard to management-based solutions, ECB maintains the water grid at an 
optimal level minimizing leakage and has initiated regular informative sessions and educational events on water saving practices starting with newly enrolled students. ECB also has information boards and signs posted at critical locations to remind the water conservation practices required at ECB to achieve behavioral changes. A further element in raising the awareness of students and staff at the ECB about the use of water as a vital resource is the provision of water dispensers. Here, anyone can fill tap water in reusable bottles provided by the ECB free of charge and in an environmentally friendly manner. Compared to mineral water, drinking water has a significantly lower product carbon footprint and the costs are also many times lower. Based on a study by the certification company GutCert, the average weighted total emission factor of mineral water including the emissions from all process steps is $273.94 \mathrm{~g} \mathrm{CO} \mathrm{e} / \mathrm{l}$. The average, weighted total emission factor of drinking water, including emissions from all process steps, is therefore only $5.64 \mathrm{~g} \mathrm{CO} 2 \mathrm{e} / \mathrm{l}$. This means that for the entire life cycle of mineral water, 49 times the emissions are to be applied as for drinking water. If no carbonic acid is added to the drinking water, the study shows that the carbon footprint per liter is much lower $0.35 \mathrm{~g}$ CO2e/I.) and in relation to still mineral water even 586 times lower [16].

Environmental impacts reduction associated with the use of water resources include: Lower water and energy demand by the use of waterless urinals and energy efficient appliances; Implementation of low-impact, alternative water supply solutions. e.g. use of rainwater (see chapter 3.2); Reduction the GHG impact of water resource use by employing renewable energy (green electricity) for water supply network; Offer tap water instead of mineral water; Assuring water quality through regular water quality monitoring; Continuous measurement and monitoring of water consumption to prevent leakages.

\subsection{Water recycling}

ECB's water recycling program for rainwater is fully implemented. To relieve the burden on fresh water sources, the campus promotes the collection of rainwater. With the help of the 2,000 $\mathrm{m} 2$ roof areas of the campus buildings, large amounts of rainfall can be collected and used in succession. The campus has a sophisticated rainwater collection and storage system (see Fig. 3) and thus uses the rainwater as a raw material for building services. The rainwater is conducted into two underground tanks, which have a combined capacity of $40 \mathrm{~m} 3$.

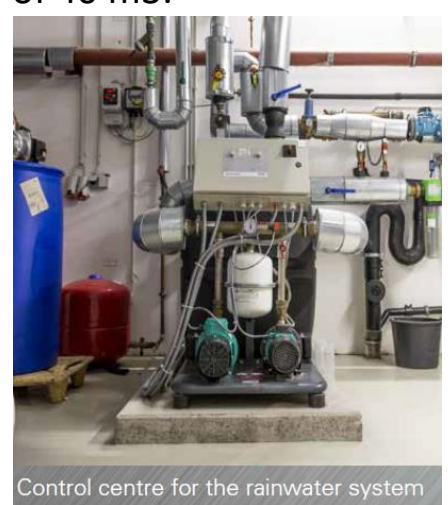

A. Rainwater harvesting system

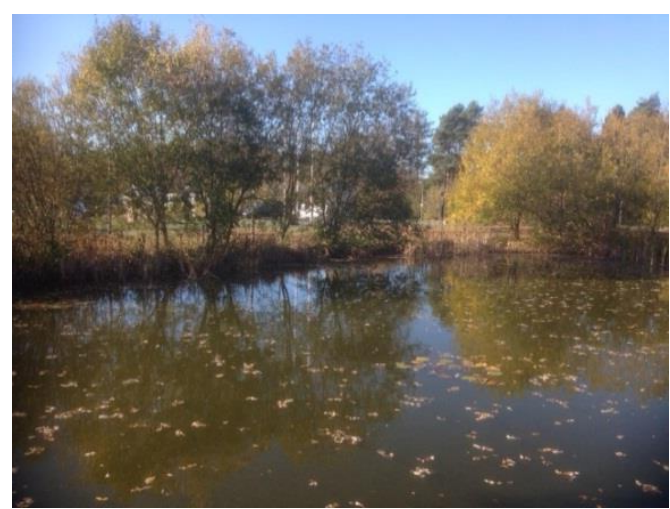

B. Rainwater collection pond and retention basin

Figure 3. Water recycling elements at ECB

The rainwater collection and storage system at ECB allows an annual saving of 800 - 
$1,000 \mathrm{~m} 3$ of freshwater from the water grid and the associated impacts and costs (such as water costs and wastewater fees). Depending on the yearly rainfall, the use of rainwater covers about one-third of the overall water demand of ECB. Most of the collected rainwater is used for flushing the toilets in six buildings and the entire central building. Approximately one third of the harvested rainwater is used for the adsorption cooling system after sanitization with ultraviolet radiation. Furthermore, rainwater is directed into retention basins at various locations on the campus where it is either allowed to seep into the soil or evapotranspiration through various purpose-built biotopes. ECB's storm water management infrastructure prevents the water quality deterioration and is designed to recharge the groundwater reservoirs by employing retention basins, an artificial pond, and the use of micro wetland-biotopes. The generous retention areas allow rainwater to seep away even during heavy rainfall events, which are also increasing in Germany in times of global warming.

Apart from the rainwater used in toilet flushing, no rainwater leaves the ECB as wastewater. The ponds of the retention system allow additionally the use of the rainwater for watering plants and for the students' garden. As a result, rainwater use relieves the municipal sewer system.

The total volume of sewage generated at ECB is treated in a nearby (approx. $4 \mathrm{~km}$ ) communal biological wastewater treatment facility with an activated-sludge process. Through a combination of energy- efficient technologies, the energy demand of the plant and also the specific carbon footprint per treated cubic metre of wastewater is kept to a minimum. Subsequent to the treatment process the clean water is released to the local river "Nahe" augmenting the natural water cycle. The remaining sludge is disposed of according to the German regulation for wastewater treatment. The wastewater treatment plant is already being operated in an energy-efficient manner, among other things with demand-controlled basin aeration. At the suggestion of the ECB, the wastewater treatment plant in Hoppstädten-Weiersbach is being further developed into an energy self-sufficient wastewater treatment plant. For this purpose, a large PV system is currently being planned, the electricity of which is to be used directly in the wastewater treatment plant, as well as the conversion from aerobic sludge stabilization to anaerobic sludge digestion. The generated digester gas (biogas) is used in a combined ceat and power unit (CHP) to generate electricity and heat and contribute to covering the energy needs of the treatment plant.

\subsection{Zero emission water management and nutrient mining}

As part of the ECB's initiative for wastewater reduction and resource recovery, a research project on "Zero Emission Water Management and Nutrient Mining" is currently running under the leadership of the Institute for Applied Material Flow Management (IfaS) $[17,18]$.

In view of current challenges such as climate change, rising raw material prices, demographic development or scarcity of raw materials, new alternative sanitation systems are increasingly becoming the focus of infrastructural considerations. An essential component of such systems is the separate collection of the partial streams of domestic wastewater produced in residential buildings. In new buildings, an implementation of the separation technology can be taken into account from the very beginning of the planning phase and implemented at comparatively low cost. In contrast, the installation of a second pipe in the existing building is associated with high effort and costs, provided that the 
available space in the installation shaft is sufficient. One solution here is the method developed in the "EVaSENS" project [19]. The approach is based on a technical novelty, the double inliner process in combination with a vacuum system to drain off the black water. This makes it possible to retrofit existing buildings with a separate black water pipe more quickly, cleanly and economically. This process is now being implemented in practice for the first time in the project "Real-Laboratory Wastewater-free Environmental Campus Birkenfeld (ReLab)" on the basis of a concrete application object.

For this purpose, an existing dormitory at the ECB was converted (see Fig. 4) in such a way that the separate collection and discharge of the partial streams grey and black water is possible. A total of 24 residential units (14 toilets / 14 showers / 3 kitchenettes) were converted within the 3-year project duration. First of all, all existing flush toilets were replaced with vacuum toilets. In order to enable a comparison of the conversion procedures, two approaches were taken into account for the subsequent separate collection of the grey and black water partial flows. For some of the residential units (7 showers, 7 toilets, 7 hand basin and 3 kitchenettes), a second pipe was installed in spring 2019 , in which black water is drained off by means of negative pressure. For the second part of the residential units ( 6 showers, 6 toilets and 6 hand basin) an inversion of the existing downpipe was carried out in autumn 2019.
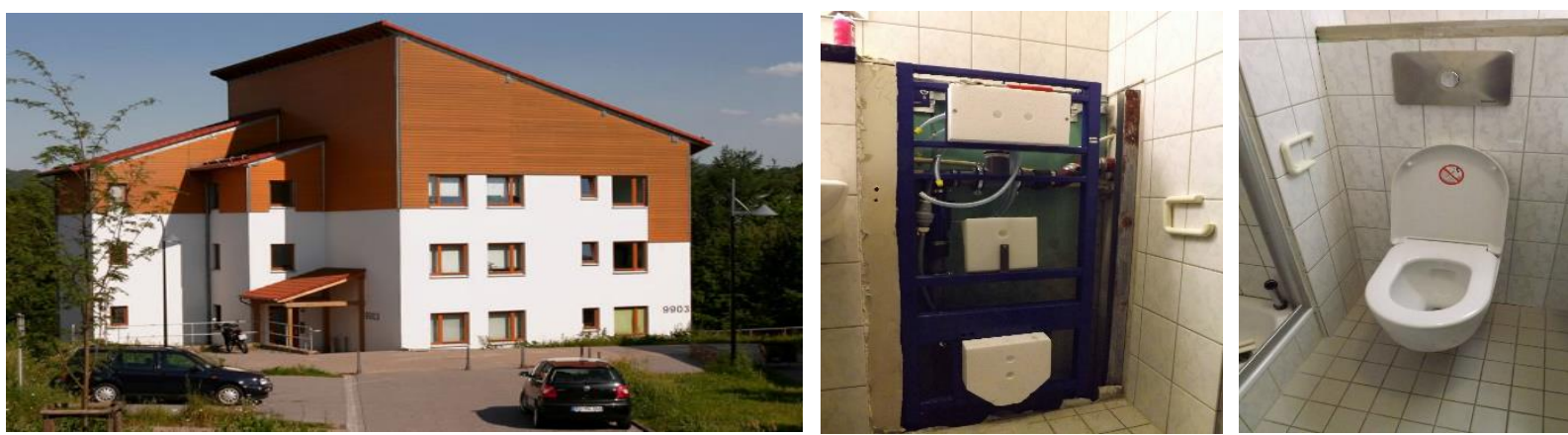

Figure 4. Project dormitory and installation of vacuum pre-wall system and vacuum toilet

Due to the arrangement of the connecting pipes to the downpipe in the building, the challenge here isthat the inversion cannot be carried out as planned using double inliners. The reason for this is the arrangement of the grey and black water connection of ideally $180^{\circ}$ to each other, which is predetermined by the two double inliner components. For technical reasons, this arrangement can only be deviated from to a limited extent. To solve this problem, the inversion method was further developed into a "pipe-in-pipe" system and tested in practice. In contrast to the method used in the EVaSENS project with the double inliner, only one inliner was introduced into the existing drainpipe. This has the major advantage that the existing disposal lines on the drainpipe can still be used for grey water.

Fixing the inliner in the drainpipe and connecting the black water pipe from the toilet to the drainpipe is one of the main challenges. In order to make this possible in a "simple" and practical way, a suitable fitting was developed and manufactured in the laboratory for additive manufacturing at the ECB (see Fig. 5). The developed solution approach represents a future-oriented technical supplement for the comprehensive economic integration of subsequent material flow separation in buildings. In order to ensure a safe installation, various tests were carried out with regard to tightness (water 
impermeability) and pressure resistance.

Due to the structural adjustments, it also became apparent that the installation of decentralized waste shredders for the joint collection of biowaste and black water is not appropriate. In contrast, a centralized collection of bio-waste for the model building is simpler and much more target oriented. For this purpose, the partner Aqseptence has developed a suitable "waste station" capable of under-pressure, which can be installed and tested on the model building in the course of the year. The installation of a mini-biogas plant $(5 \mathrm{~m} 3)$ at the ECB is planned for the practical testing of the energetic utilization of black water and biowaste. Here, the biowaste from the "waste station", the food leftovers and fats from the canteen and the collected black water from the dormitory will be processed.

The project is also be accompanied by scientific partners who will examine the separately collected resource flows in detail. For black water, the focus is on studies of fermentability in connection with the bio-waste produced. The aim of the greywater investigations is to evaluate the different treatment processes for the ECB site on the basis of the quantities and qualities determined. Based on these investigations, an overall concept for the partial streams at ECB will be developed. In addition, an evaluation of the transferability of the results is carried out.

\section{Concluding Remark}

A holistic approach is needed to enable universities to fulfil their responsibility for sustainable development and to contribute to the implementation of Agenda 2030 with its 17 SDGs. Water is the source of life and should therefore play a central role in universities, which are the source of knowledge. Universities develop solutions for the sustainable use of water and open opportunities for further innovation through high-quality education. The example of the ECB has shown that sustainable water management requires an interdisciplinary approach in teaching, research and knowledge transfer. Furthermore, it is important to design the strategy and operation of the university in such a way that water resources are used responsibly. The approaches presented in the field of water conservation and water recycling at the ECB provide important suggestions for other universities. E.g., the use of waterless urinals, the collection of rainwater and the environmentally friendly, energy-efficient treatment of unavoidable wastewater should be a matter of course. These are comprehensive sustainable solutions with positive impact on the environment, the social atmosphere on the campus and mostly with positive economic impact. At the ECB, with the help of the research project "Zero Emission Water Management and Nutrient Mining " described above, the ambitious goal of a wastewater-free university is being considered even further. Current and future research projects will focus on other approaches and applications in the field of innovative water management and the interaction between water-related topics to other SDGs.

\section{References}

1. UN General Assembly, 2015. Transforming our world: the 2030 Agenda for Sustainable Development, 21 October 2015, A/RES/70/1. Available online at https://www.refworld.org/docid/57b6e3e44.html, accessed on 31 August 2020

2. UN Water, 2020. Water Security and the Global Water Agenda, Available online at https://www.unwater.org/publications/water-security-global-water-agenda/, accessed on 03 September 2020 
3. Elaydi, H., 2017. The Water-Food-Displacement Nexus, In: From Politics to Policy building Regional Resilience in West Asia and North Africa, WANA Institute and Friedrich Ebert Stiftung (Ed.), Amman Jordan, pp 122-132

4. ECB Green Campus Concept. Available online at https://www.umweltcampus.de/en/campus/life-on-campus/green-campus-concept, accessed on 03 September 2020

5. University of Applied Sciences Trier, 2020. Main Research Areas. Available online at https://www.hochschule-trier.de/en/research/research-profile/main-research-areas, accessed on 03 September 2020

6. Hochschulrektorenkonferenz, 2020. Research Map Universities of Applied Sciences. Available online at https://www.forschungslandkarte.de/en/institutional-researchpriorities-at-universities-of-applied-sciences/map-search.html, accessed on 03 September 2020

7. Umwelt-Campus Birkenfeld, 2020. DNK-Erklärung 2018 des Umwelt-Campus Birkenfeld der Hochschule Trier. Available online at https://datenbank2.deutschernachhaltigkeitskodex.de/Profile/CompanyProfile/12157/de/2018/dnk, accessed 14 June 2020

8. Helling, K., 2017. Environmental Campus Birkenfeld -A Role Model for Universities on How to Contribute to the Implementation Process of the Sustainable Development Goals, In: Handbook of Sustainability Science and Research, Leal, W. (Ed.), Springer, pp. 539 552

9. Deutsche UNESCO Kommission, 2018. Ausgezeichneter Lernort Umwelt-Campus Birkenfeld. Available online at https://www.unesco.de/bildung/bne-akteure/umweltcampus-birkenfeld-der-hochschule-trier, accessed 14 June 2020

10. UI GreenMetric, 2019. UI GreenMetric world university ranking. Available online at http://greenmetric.ui.ac.id/, accessed on 03 September 2020

11. Helling, K., Rick, K., 2017. Environmental Campus Birkenfeld - A model University Site successfully combining theory and practise for a sustainable future, $\ln$ : Proceedings $3^{\text {rd }}$ International Workshop on UI Greenmetric in Istanbul, Universitas Indonesia (Ed.) pp. 31 $-39$

12. Helling, K., 2019. Mission Zero Emission - Managing Energy and Climate Change at the Environmental Campus Birkenfeld, In: Proceedings 4th International Workshop on UI GreenMetric World University Rankings in Cork, Universitas Indonesia (Ed.) pp. 6469

13. Umwelt-Campus Birkenfeld, 2020. Study Programmes \& Continuing Education. Available online at https://www.umwelt-campus.de/en/study/study-programmes-continuingeducation, accessed on 04 September 2020

14. Umwelt-Campus Birkenfeld, 2020. Investigation of Renaturalised Water Bodies. Available online at https://www.umwelt-campus.de/en/forschung/projekte/discoverprojects/investigation-of-renaturalised-water-bodies, accessed on 03 September 2020

15. Wuppertal Institut, 2010. Öko-Innovationen: Wasserlose Urinale - kein Wasserverbrauch und mehr Hygiene. Available online at https://wupperinst.org/fa/redaktion/downloads/publications/Ecolnno_Urinals_de.pdf, accessed 01 September 2020

16. GUT Cert, 2020. Vergleich des CO2-Fußabdrucks von Mineral- und Trinkwasser. Available online at https://atiptap.org/files/studie_gutcert_pcf_wasser.pdf, accessed 01 September 2020

17. Angilella M., 2020. Zwischenbericht zum Forschungsvorhaben ReLab - Real-Labor 
„Abwasserfreier Umwelt-Campus Birkenfeld“: Neue Technologien in der Gebäudesanierung für eine zukunftsfähige Ressourcenwirtschaft. Berichtszeitraum 01.10.2018-31.12.2019, FKZ SWD-10.08.18.7-17.64, Hoppstädten-Weiersbach

18. IfaS, 2020. Institute for Applied Material Flow Management. Available online at https://www.stoffstrom.org/?lang=en, accessed 01 September 2020

19. Veser, S., Londong, J., 2017. EVaSENS - Einsatz von Vakuum-Inlinern im Bestand Integration von Unterdruck-Sanitärtechnik im bestehenden Gebäude zur Etablierung von NASS-Systemen. Available online at https://www.irbnet.de/daten/rswb /17079006196.pdf, accessed 02 September 2020 